Utah State University

DigitalCommons@USU

1952

\title{
Yearly Population Fluctuation of Bombus morrisoni at Fredonia, Arizona
}

George E. Bohart

Utah State University

George F. Knowlton

Follow this and additional works at: https://digitalcommons.usu.edu/piru_pubs

Part of the Entomology Commons

\section{Recommended Citation}

Bohart, George E., and George F. Knowlton. 1952. Yearly Population Fluctuation of Bombus morrisoni at Fredonia, Arizona. Jour. Econ. Ent. 45(5): 890-891.

This Article is brought to you for free and open access by the Pollinating Insects Research Unit at DigitalCommons@USU. It has been accepted for inclusion in All PIRU Publications by an authorized administrator of DigitalCommons@USU. For more information, please contact digitalcommons@usu.edu.

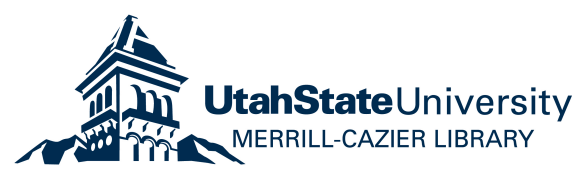




\section{YEARLY POPULATION FLUCTUATION OF Bombus morrisoni AT FREDONIA, ARIZONA}

GEORGE E. BOHART, U.S.D.A., Agr. Res. Adm., Bureau of Entomology and Plant Quarantine, and GEORGE F. KNOILTON, Utah State Agricultural College, Logan

Bumble bees are valuable pollinators of various fruit and seed crops, but their usefulness is limited by their tendency to fluctuate strongly in abundance from year to year. This report concerns Bombus morrisoni Cresson ${ }^{1}$, one of the most important native pollinators of alfalfa in many intermountain localities.

Fredonia, Arizona, is a small community isolated by nearly five miles from the farms of the larger town of Kanab, Utah. Its few alfalfa seed farms are surrounded by semidesert range lands. Normally, the area supports enough wild flowers in April and May to meet the needs of overwintering queen bumble bees during their nest founding.

In 1948 and 1949 unusually large populations of Bombus morrisoni were present on the alfalfa seed fields during July and August. With favorable growing conditions and adequate insect control, the Thomas Jensen farm yielded approximately 840 pounds of clean seed per acre of the 40 acres left for second-crop seed in 1948. In 1949, the farmer reported a yield of 700 pounds per acre. The spring of 1950 was particularly dry and cold and farmers of the area reported that spring flowers were practically absent. Frost destroyed most of the early blooming garden flowers that might have provided some forage for the overwintered queens. Apparently as a result of these unfavorable spring conditions, bumble bees vere rare in the Fredonia alfalfa seed fields during 1950. In June, before the alfalfa was in bloom, one queen and a few workers were seen near a barn. In July during peak bloom of the alfalfa no bumble bees were seen during an hour of observation. Honey bees were brought into Fredonia for the first time to aid in alfalfa pollination. Mr. Jensen had 30 colonies. placed by the 60 acres that he left for second-crop seed, but his production of seed dropped to 180 pounds per acre. This concentration of colonies is generally considered insufficient for adequate pollination of alfalfa.

In 1951, the population of Bombus morrisoni increased markedly on the Jensen field but was still only about 10 per cent as large as in 1949 . This time $\mathrm{Mr}$. Jensen arranged for 50 colonies of honey bees to be placed on the 75 acres that he left for second-crop seed. His yield in 1951 was 400 pounds per acre.

On the Kanab fields, this bumble bee followed the same trends. However, populations were not so high during the two seasons prior to 1950, and in 1951 they more nearly approached the levels of 1948 and 1949. Sixteen miles to the east of Kanab, in Johnson Canyon, Utah, there was only a moderate decline in bumble bee populations in 1950. Yields in those two areas did not show a general decline in 1950. This may be explained by better control in injurious insects and $t \cdot e$ inauguration in 1950 of planned pollination with honey bees. Seed growers in the above mentioned areas have generally followed the insect control measures recomended by 
Population Fluctuation of Bombus norrisoni - Page 2

the State Experiment Station. In 1950 and 1951 Lygus bugs were held to a low level in most fields and there was no reason to suspect poisoning of bees since bloom stage applications were avoided.

At Fredonia, as in many other seed areas, it obviously would be vise to help the wild pollinators to survive adverse conditions. It seems likely that if a few acres of irrigated spring forage, such as vetch had been provided for the bees in 1950, survival of queens and colony buildup would have been much better. It should be worthwhile for grovers of any crop pollinated by bees to insure a succession of bloom in the area throughout the growing season.

1 Hymenoptera: Apidae.

Ref: Journal of Economic Entomology, Vo1. 45, No. 5, pp. 890-891. 1952. 